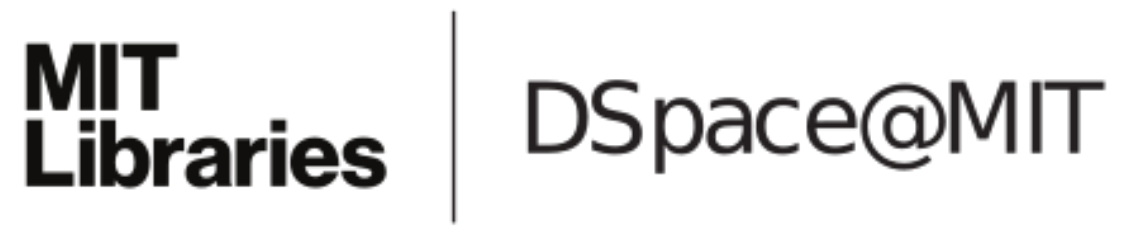

\author{
MIT Open Access Articles
}

A new route to silyl-substituted cyclobutenones and silylketenes

The MIT Faculty has made this article openly available. Please share how this access benefits you. Your story matters.

Citation: Benda, Konstantin, Tanja Knoth, Rick L. Danheiser, and Ernst Schaumann. "A new route to silyl-substituted cyclobutenones and silylketenes." Tetrahedron Letters 52 (2011), pp. 46-48.

As Published: http://dx.doi.org/10.1016/j.tetlet.2010.10.130

Publisher: Elsevier

Persistent URL: http://hdl.handle.net/1721.1/104837

Version: Author's final manuscript: final author's manuscript post peer review, without publisher's formatting or copy editing

Terms of use: Creative Commons Attribution-NonCommercial-NoDerivs License 
Tetrahedron Lett. 2011 January 5; 52(1): 46-48. doi:10.1016/j.tetlet.2010.10.130.

\title{
A New Route to Silyl-substituted Cyclobutenones and Silylketenes
}

\author{
Konstantin Benda ${ }^{a}$, Tanja Knoth ${ }^{a}$, Rick L. Danheiser ${ }^{b}$, and Ernst Schaumann ${ }^{a}{ }^{*}$ \\ aInstitut für Organische Chemie, Technische Universität Clausthal, Leibnizstraße 6, 38678 \\ Clausthal-Zellerfeld, Germany \\ bDepartment of Chemistry, Masschusetts Institute of Technology, Cambridge, MA 02139, USA
}

\begin{abstract}
2-Silyl-cyclobutene(di)ones are obtained by an addition/substitution approach on dimethyl squarate using silyl anions. The acetal and in particular the thioacetal derivatives readily undergo electrocyclic ring opening to reactive silyl(vinyl)ketenes.
\end{abstract}

\section{Keywords}

Silyl anions; Cyclobutenones; Silylketenes; Cyclopentenones; Cycloaddition Reactions

\section{Introduction}

1-Alkenyl(silyl)ketenes ("silyl(vinyl)ketenes") $\mathbf{1}^{1}$ show remarkable stability, but are sufficiently reactive especially in cycloaddition chemistry to make them attractive synthetic building-blocks, $2-4$ including in applications such as natural product synthesis.5 Four main routes have been described for their synthesis which, however, suffer from certain drawbacks (Scheme 1). Thus, the dehydrohalogenation of appropriately substituted acyl chlorides $\mathbf{2}$ is limited to produce vinylketenes in which $\mathrm{R}^{2}=\mathrm{H}$ in order to avoid regiochemical ambiguity. ${ }^{6}$ Similarly, the Wolff rearrangement of $\alpha, \beta$-unsaturated $\alpha^{\prime}$ diazoketones 3 works best for purely aliphatic 1 -alkenyl substitution. ${ }^{2}$ The outcome of the reaction of silyl-substituted alkynes $\mathbf{4}$ with Fischer carbene complexes $\mathbf{5}$ depends on the size of the silyl substituent and is limited to the preparation of vinylketenes in which $\mathrm{R}^{4}$ is an alkoxy group. $.5,7,8$ Finally, the $[2+2]$ cycloaddition of aryl(silyl)acetylenes $4\left(\mathrm{R}^{2}=\right.$ aryl $)$ with dichloroketene and subsequent dehalogenation gives 2-silyl-cyclobutenones and from there the corresponding silylketenes, but the regioselectivity in the cycloaddition step can only be secured when $\mathrm{R}^{2}$ is an aryl substituent. ${ }^{2}$ So it appeared attractive to develop an independent method for regiospecific introduction of a silyl substituent into the cyclobutenone ring.

() 2010 Elsevier Ltd. All rights reserved

"Corresponding author. Tel.: +49-5323-72-2519; fax: +49-5323-72-2858. ernst.schaumann@tu-clausthal.de.

Publisher's Disclaimer: This is a PDF file of an unedited manuscript that has been accepted for publication. As a service to our customers we are providing this early version of the manuscript. The manuscript will undergo copyediting, typesetting, and review of the resulting proof before it is published in its final citable form. Please note that during the production process errors may be discovered which could affect the content, and all legal disclaimers that apply to the journal pertain. 


\section{Results and discussion}

Dialkyl squarates $\mathbf{7}$ are excellent starting materials for the synthesis of cyclobutene(di)ones.

9,10 In a convenient one-pot reaction sequence, carbanions are first added to 7 , the resulting alkoxide is trifluoroacetylated to 8 , and then a nucleophile is introduced in an $S_{N} 2$ ' process to give intermediate $\mathbf{9}$ (Scheme 2). ${ }^{11-13}$ Thus, with water as nucleophile cyclobutenediones are formed via the hemiacetal, the use of alcohols as nucleophile leads to acetals, and the addition of amines produces cyclobutenimines. ${ }^{14}$ We reasoned that this approach might be amenable to the introduction of a silyl residue if a silyl anion ${ }^{15}$ is used as attacking nucleophile in the 1,2 addition step $\left(\mathrm{R}^{2}=\right.$ silyl). In fact, silyl anions $\mathbf{1 0 a}-\mathbf{c}$ turned out to give a smooth addition to squarate $7\left(\mathrm{R}^{1}=\mathrm{Me}\right)$ and, depending on the method of work-up, provide diones of type $\mathbf{7}$ (one silyl instead of $\mathrm{MeO}$ ) or acetals 11a-c (Scheme 3).${ }^{16}$ Isolated yields are good for 11a and 11b, but probably due to steric reasons, 11 $\mathbf{c}$ is formed only in trace amounts (Table 1). Products $\mathbf{1 1}$ are stable at room temperature and show no apparent tendency to undergo ring opening to silylketenes $\mathbf{1 2}$.

Interestingly, the remaining methoxy group in methoxycyclobutenone 11a can be exchanged for a methyl or phenyl group following the addition/substitution approach outlined in Scheme 2. Thus, with methyl or phenyllithium and after aqueous work-up, cyclobutenones 13a $(57 \%)$ and 13b (77\%) are formed (Scheme 4).

In a further modification, the acetal group in acetals $\mathbf{1 1 a}, \mathbf{b}$ and $\mathbf{1 3 a}, \mathbf{b}$ can be transformed into a thioacetal group which, if a dithiolane is formed, can be considered as a latent thione unit (Scheme 5). ${ }^{17}$ As in earlier studies, ${ }^{18,19}$ zirconium tetrachloride turned out to be the most efficient Lewis acid catalyst for this transformation. However, yields remain relatively low as in contrast to acetals 11, 13, thioacetals $\mathbf{1 4}$ show, even at room temperature, a pronounced tendency to undergo electrocyclic ring opening to give silylketenes 15 which display variable stability. Thus, immediately after chromatographic purification, products 14 already show the characteristic ketene vibration at $2100 \mathrm{~cm}^{-1}$ in the IR spectra. The best yield is obtained for thioacetal $\mathbf{1 4 c}$, followed by $\mathbf{1 4 d}$, while the methoxy-substituted derivative 14a is isolated in lower yield and $\mathbf{1 4 b}$ only in trace amounts (Table 1). For 14c, complete conversion into silylketene $\mathbf{1 5} \mathbf{b}^{20}$ is achieved by heating to $90{ }^{\circ} \mathrm{C}$ in toluene for 30 $\min$. However, due to the limited stability of ketenes $\mathbf{1 5}$ and the corresponding species derived from acetals $\mathbf{1 3}$ it is advantageous to use precursors 12-14 in reactions and generate the silylketene in situ.

In previous studies, silylketenes have been shown to be useful substrates for reaction with $\mathrm{C}_{1}$ transfer reagents to give cyclopentenones in a [4+1] approach.21-23 A particularly smooth reaction had been observed for (trimethylsilyl)diazomethane21 and this is now confirmed for the reaction with the novel silylcyclobutenones / silylketenes 11-14/15 (Scheme 6). ${ }^{24}$ Generally good yields (50-74\%) ${ }^{25}$ are obtained both from acetals $\mathbf{1 1}$ and $\mathbf{1 3}$ and from thioacetals 14 implying that at temperatures above $90{ }^{\circ} \mathrm{C}$ ketene intermediates of type $\mathbf{1 5}$ are also formed from acetals $\mathbf{1 1}, \mathbf{1 3}$ which at room temperature are stable compounds with no apparent tendency to undergo electrocyclic ring opening. However, only trace amounts of cyclopentenone products $\mathbf{1 6 c}, \mathbf{f}$ are formed from silylcyclobutenones 13a and $\mathbf{1 4 b}$ where the corresponding ketene intermediates $\mathbf{1 5}$ are apparently quite labile and preferably undergo decomposition.

The inherent $4 \pi$ system in vinylketenes 15 invites the use of precursors 11,13 , and 14 as dienes in Diels-Alder chemistry. ${ }^{2}$ Here we had little success with olefinic reaction partners. Only tetracyanoethylene gives a smooth reaction with thioacetals $\mathbf{1 4 c}, \mathbf{d}$, but no cycloadduct 17 with 3-methoxy-cyclobutenone 14a (Scheme 7). The alternative 2-alkenyl-cyclobutanone 
structure for $\mathbf{1 7}$ can be ruled out because of a carbonyl vibration at relatively low wavenumber around $1700 \mathrm{~cm}^{-1}$.

[2+2] Cycloadditions of cyclobutenones 14 with $\mathrm{C}=\mathrm{N}$ systems turned out to be more successful. In particular, 14d undergoes a smooth reaction with $N$-methyl-4nitrobenzaldimine to give $\beta$-lactam 18 in two diasteromeric forms with a characteristic carbonyl absorption at $1740 \mathrm{~cm}^{-1}$ (Scheme 7). Under the reaction conditions, ketene 15a from cyclobutenone $14 \mathbf{a}$ apparently decomposes and $\mathbf{1 4 c / 1 5 c}$ gives no reaction. In contrast, $N$-silylimines and silylketene precursors $\mathbf{1 4 c}, \mathbf{d}$ give $\delta$-lactams 19a-d, ${ }^{26}$ but to obtain the indicated yields of $16-72 \%$ catalysis by zinc triflate is required; the aqueous work-up leads to $N$-desilylation.

\section{Conclusion}

The addition/substitution method (Scheme 2) offers convenient access to silylcyclobutenones. Acetals $\mathbf{1 1}$ show no spontaneous electrocyclic ring opening to silylketenes 12, but the ketene species is apparently formed on heating with silyldiazomethane and trapped to give cyclopentenones 16a-d. Thioacetals 14a-d are in equilibrium with silylketenes $\mathbf{1 5}$, which can be trapped to 16-19, but decomposition of $\mathbf{1 5}$ sometimes interferes.

\section{Acknowledgments}

Support of our work by the Fonds der Chemischen Industrie, Frankfurt, and the U. S. National Institutes of Health (GM 28273 to R.L.D.) is gratefully acknowledged.

\section{References and notes}

1. Reviews: (a) Tidwell, TT. Ketenes. 2nd ed.. Wiley; Hoboken, NJ: 2006. p. 342-361.. (b) Pons, J-M.; Kocienski, PJ. Science of Synthesis. Fleming, I., editor. Vol. Vol. 4. Thieme; Stuttgart, Germany: 2002. p. 657-668.. (c) George, DM.; Danheiser, RL. Science of Synthesis. Danheiser, RL., editor. Vol. Vol. 23. Thieme; Stuttgart, Germany: 2006. p. 53-99.. (d) Pommier A, Kocienski P, Pons J-M. J. Chem. Soc., Perkin 'Trans 1998;1:2105-2118..

2. Loebach JL, Bennett DM, Danheiser RL. J. Org. Chem 1998;63:8380-8389.

3. Bennett DM, Okamoto I, Danheiser RL. Org. Lett 1999;1:641-644. [PubMed: 10823193]

4. Austin WF, Zhang Y, Danheiser RL. Org. Lett 2005;7:3905-3908. [PubMed: 16119928]

5. Giese MW, Moser WH. Org. Lett 2008;10:4215-4218. [PubMed: 18754622]

6. Danheiser RL, Sard H. J. Org. Chem 1980;45:4810-4812.

7. Moser WH, Sun L, Huffman JC. Org. Lett 2001;3:3389-3391. [PubMed: 11594841]

8. Li Z, Moser WH, Zhang W, Hua C, Sun L. J. Organomet. Chem 2008;693:361-367.

9. Moore HW, Yerxa BR. Chemtracts Adv. Strain Org. Chem 1992;1995;54:273-313. 81-162.

10. Liebeskind LS. Tetrahedron 1989;45:3053-3060.

11. Reed MW, Pollart DJ, Perri ST, Foland LD, Moore HW. J. Org. Chem 1988;53:2477-2482.

12. Gayo LM, Winters MP, Moore HW. J. Org. Chem 1992;57:6896-6899.

13. Liebeskind LS, Fengl RW, Wirtz KR, Shawe TT. J. Org. Chem 1988;53:2482-2488.

14. Oppermann G, Stranberg M, Moore HW, Schaumann E, Adiwijaja G. Synthesis 2010:2027-2038.

15. Sekiguchi A, Lee VY, Nanjo M. Coord. Chem. Rev 2000;210:11-45.

16. Cyclobutenone 11a, Typical Procedure: $\mathrm{Me}_{2} \mathrm{PhSiLi}(70 \mathrm{~mL}, 0.5 \mathrm{M}$ in THF, $35.0 \mathrm{mmol}$ ) was added dropwise to $7\left(\mathrm{R}^{1}=\mathrm{Me} ; 4.886 \mathrm{~g}, 34.4 \mathrm{mmol}\right)$ in dry THF $(500 \mathrm{~mL})$ at $-78{ }^{\circ} \mathrm{C}$. After $20 \mathrm{~min}$, TFAA $(5.5 \mathrm{~mL}, 34.4 \mathrm{mmol})$ was added and after another $20 \mathrm{~min}$ dry $\mathrm{MeOH}(40 \mathrm{~mL})$. The mixture was allowed to warm to rt over $30 \mathrm{~min}$ with stirring and aq. $\mathrm{NaHCO}_{3}(20 \%, 250 \mathrm{~mL})$ added. The product was extracted with ether $(2 \times 250 \mathrm{~mL})$, the ethereal solution washed with brine $(2 \times 150$ $\mathrm{mL})$, dried $\left(\mathrm{MgSO}_{4}\right)$ and concentrated in vacuo. Purification by flash chromatography $\left(\mathrm{SiO}_{2}\right.$, 
petroleum ether $/$ EtOAc $=101)$ yielded cyclobutenone 11a $(8.212 \mathrm{~g}, 46 \%)$. Yellow oil; ${ }^{\mathbf{1}} \mathbf{H}$ NMR $\left(400 \mathrm{MHz}_{\mathrm{CDCl}}\right): \delta=7.56(\mathrm{~m}, 2 \mathrm{H}), 7.38(\mathrm{~m}, 3 \mathrm{H}), 3.95(\mathrm{~s}, 3 \mathrm{H}), 3.53(\mathrm{~s}, 6 \mathrm{H}), 0.42\left(\mathrm{~s}, 6 \mathrm{H} .{ }^{\mathbf{1 3}_{\mathbf{C}}}\right.$ NMR (100 MHz, $\left.\mathrm{CDCl}_{3}\right): \delta=193.5,192.1,136.9,133.7,131.5,129.5,128.0,115.0,60.2,53.5$, -2.5 ppm. IR (film): $v=1750 \mathrm{~cm}^{-1}$. HRMS (ESI): $[\mathrm{M}+\mathrm{Na}]^{+}$found 315.1023, calcd. 315.1023.

17. Schaumann E, Winter-Extra S, Rühter G. J. Org. Chem 1990;55:4200-4202.

18. Firouzabadi H, Iranpoor N, Karimi B. Synlett 1999:319-320.

19. Regenhardt W, Schaumann E, Moore HW. Synthesis 2001:1076-1080.

20. Selected data of compounds: Ketene 15b: slightly yellow liquid. ${ }^{\mathbf{1}} \mathbf{H} \mathbf{~ N M R}\left(400 \mathrm{MHz}, \mathrm{CDCl}_{3}=\right.$ 7.26): $\delta=7.60(\mathrm{~m}, 2 \mathrm{H}), 7.39(\mathrm{~m}, 1 \mathrm{H}), 7.29-7.17(\mathrm{~m}, 3 \mathrm{H}), 3.38\left(\mathrm{~m}, 4 \mathrm{H}, \mathrm{SCH}_{2}\right), 1.77(\mathrm{~s}, 3 \mathrm{H})$, 0.49 (s, $6 \mathrm{H}) .{ }^{13} \mathrm{C}$ NMR $\left(125 \mathrm{MHz}, \mathrm{CDCl}_{3}=77.4\right): \delta=198.6,137.1,133.8,129.6,85.3,38.8$, 38.1, 24.8, 0.9, -1.6. IR (film): $v=2958,2086,1589,1428,1252,1115,982,813,734,701 \mathrm{~cm}^{-1}$. HRMS (EI): $[\mathrm{M}]^{+}$found 306.0569, calcd. 306.0568.

21. Loebach JL, Bennett DM, Danheiser RL. J. Am. Chem. Soc 1998;120:9690-9691.

22. Davie CP, Danheiser RL. Angew. Chem 2005;117:6017-6020. Angew. Chem. Int. Ed. 2005, 44, 5867-5870.

23. Li Z, Moser WH, Deng R, Sun L. J. Org. Chem 2007;72:10254-10257. [PubMed: 18004872]

24. Presented in part at the $21^{\text {st }}$ International Symposium on the Organic Chemistry of Sulfur (ISOCS $X X I$ ), Madrid, Spain, July $4^{\text {th }}$, 2004; cf. Benda K, Schaumann E. Phosphorus, Sulfur, and Silicon 2005;180:1463-1464..

25. Cyclopentenone 16a: waxy solid, $\mathrm{mp} 74{ }^{\circ} \mathrm{C}$. ${ }^{\mathbf{1}} \mathbf{H}$ NMR $\left(200 \mathrm{MHz}, \mathrm{CDCl}_{3}=7.26\right): \delta=7.37(\mathrm{~m}, 1$ H), $7.21(\mathrm{~m}, 4 \mathrm{H}), 3.47$ (s, $3 \mathrm{H}), 3.28(\mathrm{~s}, 3 \mathrm{H}), 3.14$ (s, $3 \mathrm{H}), 2.41(\mathrm{~s}, 1 \mathrm{H}), 0.06$ (s, $3 \mathrm{H}), 0.04$ (s, $3 \mathrm{H}), 0.00(\mathrm{~s}, 9 \mathrm{H}) .{ }^{13} \mathrm{C}$ NMR $\left(125 \mathrm{MHz}, \mathrm{CDCl}_{3}=77.4\right): \delta=206.7,188.8,140.6,134.5,130.0$, 128.9, 116.0, 107.9, 62.4, 52.4, 52.3, 51.1, 0.1, 0.0. IR (film): $v=2950,2899,2834,1678,1619$, 1458, 1428, 1308, 1246, 1147, 1110, 1045, 970, 841, 816, 777, 734, 701, $650 \mathrm{~cm}^{-1}$. HRMS (TOF-MS ES): $[\mathrm{M}+\mathrm{Na}]^{+}$found 401.1591, calcd. 401.1584.

26. $\delta$-Lactam 19c: colorless crystals, $\mathrm{mp} 205^{\circ} \mathrm{C} .{ }^{\mathbf{1}} \mathbf{H}$ NMR $\left(200 \mathrm{MHz}, \mathrm{CDCl}_{3}=7.26\right): \delta=7.91(\mathrm{~m}, 2$ H), $7.56(\mathrm{~m}, 2 \mathrm{H}), 7.24(\mathrm{~m}, 11 \mathrm{H}), 6.42$ (broad s, $1 \mathrm{H}), 5.29(\mathrm{~s}, 1 \mathrm{H}), 2.97(\mathrm{~m}, 4 \mathrm{H}), 0.45(\mathrm{~s}, 3 \mathrm{H})$, $0.16(\mathrm{~s}, 3 \mathrm{H}) .{ }^{13} \mathrm{C}$ NMR $\left(125 \mathrm{MHz}, \mathrm{CDCl}_{3}=77.4\right): \delta=177.4,139.3,137.0,136.9,133.0,130.5$, $129.5,129.7,129.5,128.9,128.5,67.7,48.2,39.2,38.4,1.5,0.0 . \mathbf{I R}(\mathrm{KBr}): v=3166,3056,1676$, $1491,1445,1427,1374,1348,1303,1246,1111,1018,835,818,775,730,701,652,610,544$ $\mathrm{cm}^{-1}$. HRMS (TOF-MS ES): $[\mathrm{M}+\mathrm{Na}]^{+}$found 496.1207, calcd. 496.1201. 


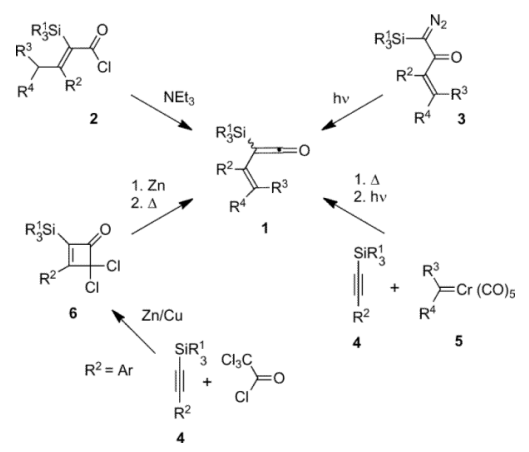

Scheme 1.

Routes to silyl(vinyl)ketenes. 


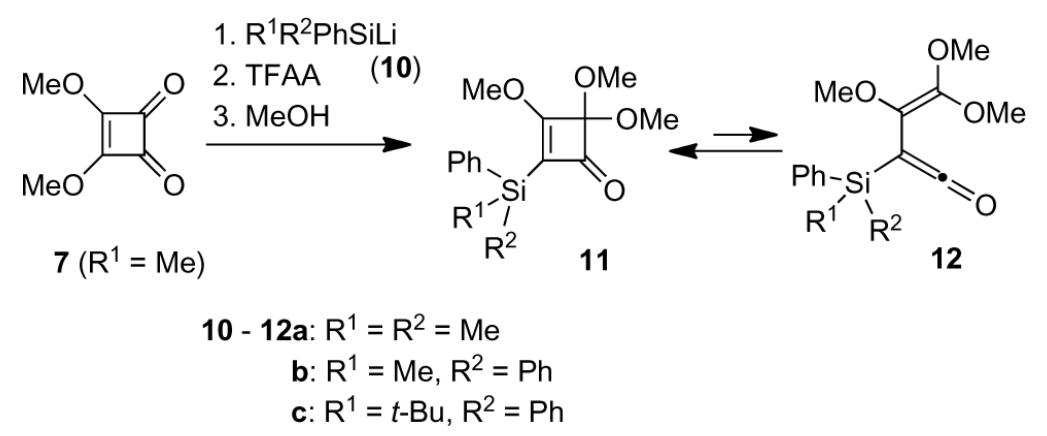

Scheme 2.

Introduction of a substituent $\mathrm{R}^{2}$ into a squarate 


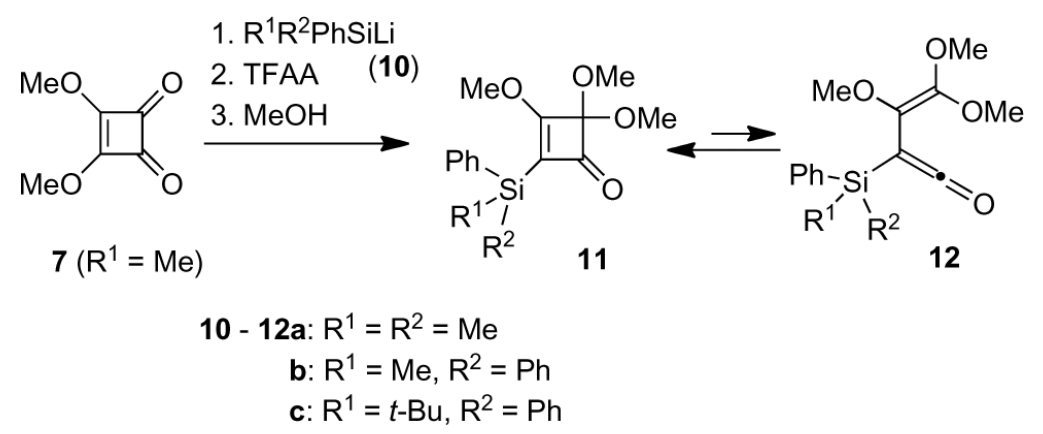

Scheme 3.

Synthesis of silyl-substituted cyclobutenones (for yields see Table 1) 


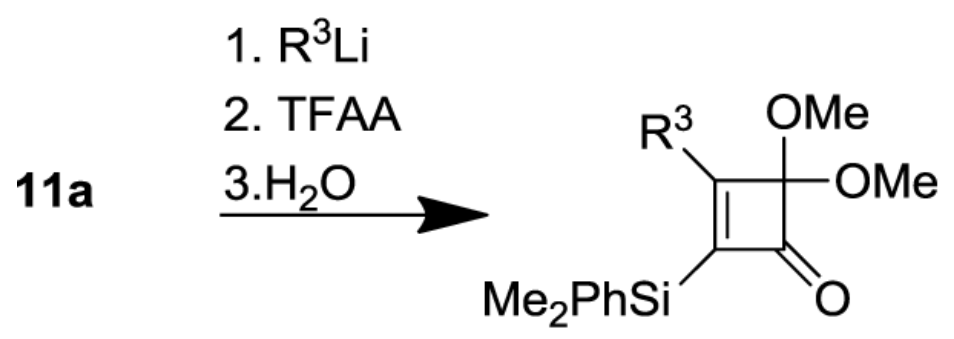

13a: $R^{3}=\operatorname{Me}(58 \%)$

13b: $R^{3}=P h(77 \%)$

Scheme 4.

Methoxy substitution in methoxy-cyclobutenone 11a. 
<smiles>[R]C1=C([Si]([R])([R])P)C(=O)C1(OC)OC</smiles>

11,13

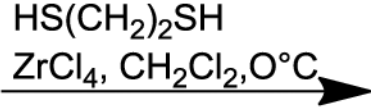

14,15a: $R^{1}=R^{2}=M e, R^{3}=O M e$

b: $R^{1}=M e, R^{2}=P h, R^{2}=O M e$

c: $R^{1}=R^{2}=R^{3}=M e$

d: $R^{1}=R^{2}=M e, R^{3}=P h$<smiles>[R]C1=C([Si]([R])([R])P)C(=O)C12SCCS2</smiles>

14<smiles>[R3]C(C(=C=O)[Si]([R])([R])[PH])=C1SCCS1</smiles>

15

Scheme 5.

Formation of thioacetals $\mathbf{1 4}$ and electrocyclic ring opening to ketenes $\mathbf{1 5}$ (for yields see Table 1). 


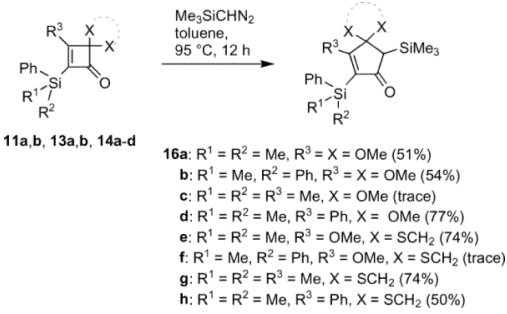

Scheme 6.

2,5-Bis-silylated cyclopentenones 16 from acetals 11,13 or thioacetals 14 . 


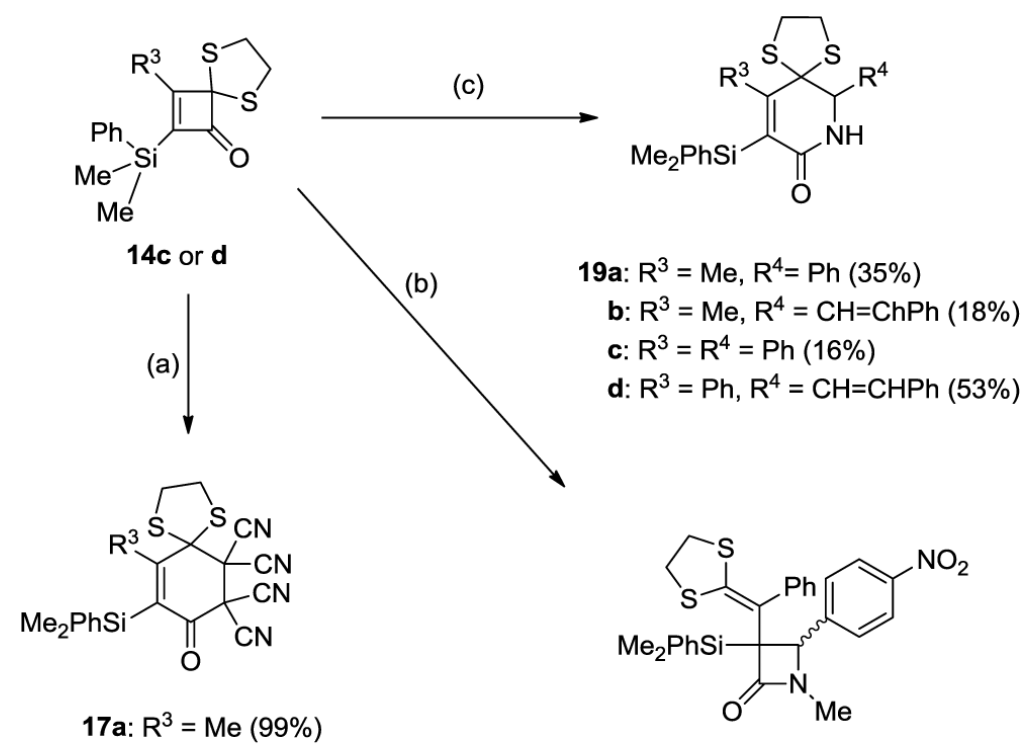

$18(40 \%)$

\section{Scheme 7.}

Formal Diels-Alder reactions of silylketene precursors 14. (a) TCNE, toluene, $110^{\circ} \mathrm{C}, 12 \mathrm{~h}$ (for 14c,d). (b) $N$-Methyl-4-nitrobenzaldimine, toluene, $110^{\circ} \mathrm{C}, 24 \mathrm{~h}$ (for $\mathbf{1 4 d}$ ). (c) TMS$\mathrm{N}=\mathrm{CH}-\mathrm{Ph}$ or TMS-N=CH-CH=CH-Ph, cat. $\mathrm{Zn}(\mathrm{Otf})_{2}$, THF, rt, $24 \mathrm{~h}$ (for 14c,d); aq. work-up. 


\section{Table 1}

Starting materials, products, and yields in the reactions of Schemes 3, 5

\begin{tabular}{llll}
\hline Entry & Starting Material & Product & Yield [\%] \\
\hline 1 & $7\left(\mathrm{R}^{1}=\mathrm{Me}\right)$ & $\mathbf{1 1 a}$ & 82 \\
2 & $7\left(\mathrm{R}^{1}=\mathrm{Me}\right)$ & $\mathbf{1 1 b}$ & 49 \\
3 & $7\left(\mathrm{R}^{1}=\mathrm{Me}\right)$ & $\mathbf{1 1 c}$ & trace \\
6 & $\mathbf{1 1 a}$ & $\mathbf{1 4 a}$ & 29 \\
7 & $\mathbf{1 1 b}$ & $\mathbf{1 4 b}$ & trace \\
8 & $\mathbf{1 3 a}$ & $\mathbf{1 4 c}$ & 57 \\
9 & $\mathbf{1 3 b}$ & $\mathbf{1 4 d}$ & 32 \\
\hline
\end{tabular}

